УДК 615:001.981]:613.98(477)«194/199»(091)

DOI https://doi.org/10.31470/2518-7732-2019-1(15)-102-107

\section{Паліснко Ольга,}

кандидат історичних наук, доцент

кафедри медико-біологічних дисциплін і

валеології,

olgapalienko03@gmail.com

https://orcid.org/0000-0002-1832-7154

Державний вищий навчальний заклад

«Переяслав-Хмельницький державний

педагогічний університет імені Григорія

Сковороди»,

м. Переяслав-Хмельницький,

вул. Сухомлинського, 30,

Київська обл., Україна, 08401

\section{Срічева Тамара,}

старший викладач кафедри медико-біологічних

дисциплін і валеології,

tamara.ericheva@gmail.com

https://orcid.org/0000-0003-0334-1073

Державний вищий навчальний заклад

«Переяслав-Хмельницький державний

педагогічний університет імені Григорія

Сковороди»,

м. Переяслав-Хмельницький,

вул. Сухомлинського, 30, Київська обл.,

Україна, 08401

\section{Palienko Olga,}

Candidate of Historical Sciences

Department Medical and Biological Disciplines

and Valeology,

olgapalienko03@gmail.com

https://orcid.org/0000-0002-1832-7154

Pereiaslav-Khmelnytskyi Hryhorii Skovoroda

State Pedagogical University,

30, Sukhomlynsky Str.,

Pereiaslav-Khmelnytskyi,

Kyiv region, Ukraine, 08401

\title{
Дослідженнях академіка В. В. Фролькіса з вікової фармакології: наукові пошуки засобів продовження життя
}

\section{Ericheva Tamara,}

Senior Lecturer Department Medical and

Biological Disciplines and Valeology,

tamara.ericheva@gmail.com

https://orcid.org/0000-0003-0334-1073

Pereiaslav-Khmelnytskyi Hryhorii Skovoroda

State Pedagogical University,

30, Sukhomlynsky Str., Pereiaslav-

Khmelnytskyi, Kyiv region, Ukraine, 08401

Метою статті є з 'ясування внеску академіка В. В. Фролькіса в розвиток і становлення вікової фармакологї в Україні 40-90-х рр. ХХ ст.

У результаті дослідження з'ясовано, щзо вчений здійснив значний внесок у розвиток $і$ становлення вікової фармакології в Україні. Зокрема, дослідження академіка В. В. Фролькіса, були спрямовані на визначення вікових передумов розвитку патологї старіючого організму, можливості ї̈ прогнозування, розробку спеціальних засобів впливу на організм. Вчений довів, що найбільи надійним і універсальним засобом попередження вікової патологіі може стати вплив на процеси старіння. 3 иієї точки зору вчений велику увагу приділяв розробиі геріатричних препаратів, здатних нормалізувати обмінні процеси, підвищувати адаптаційні можливості організму. Він покладав свої надії та очікування на позитивний результат у вирішенні проблеми старіння на гормональні препарати, нейромедіатори, інгібітори біосинтезу білка, генну терапію тощо. Ці сподівання узгоджуються з уявленнями геронтологів про локалізацію фундаментальних механізмів старіння. Вчений у пошуках засобів продовження життя, дотримувався виведеного ним самим правила, щчо засоби продовження життя повинні впливати не лише на кількість, а й на його якість.

Ключові слова: вікова фармакологія, геронтологія, прочеси старіння, геріатричні препарати, вітаміни, геропротектори.

\section{Developmental pharmacology research of academician V. V. Frolkis: scientific searches of the means to the continuation of life}

The aim of the study is to explore the contribution of academician Vladimir Frolkis in the development and formation of developmental pharmacology in Ukraine in the 1940s and $90 \mathrm{~s}$.

The study revealed that the scholar made a significant contribution to the development and formation of developmental pharmacology in Ukraine. In particular, the research of academician Vladimir Frolkis were aimed at determining the age preconditions for a developing pathology of the aging organism, the possibility of its prediction and the development of the special means of an effect on the organism. The scholar has proved that the most reliable and universal mean for preventing age pathology can be an effect on aging processes. Therefore, he paid more attention to the development of geriatric preparations, which can normalize metabolic processes and increase the adaptive capacity of the organism. He hoped and expected that his result would be positive in solving the problem of aging concerning hormonal 
preparations, neurotransmitters, protein biosynthesis inhibitors, gene and so on. These hopes are consistent with the ideas of gerontologists about the localization of the fundamental mechanisms of aging. Academician Vladimir Frolkis, in search of the means to the continuation of life and studying an effect on various levels of organization of the human organism, adhered to his derived rule that the means to the continuation of life have affect not only on the quantity but also on its quality. Under the guidance of the scholar, preparations were synthesized, in particular, a new class of antiarrhythmic preparations, an anticholinesterase preparation and cholinesterase reagents are being used in the clinic. All these preparations are registered as inventions. On the initiative of academician Vladimir Frolkis was created a number of geriatric preparations: decamevit, quadevit, neurogerin, cagliutam, rickavit, quercetin, ampervit, orcomin, corargin. The large part of the developments (including pharma preparations) was introduced into production and medical practice, although the transition to the market and other peculiarities of the Ukrainian economy and mentality slowed-down the introduction of a number of the preparations in Ukraine. The scholar also identified a class of special substances heroprotectors that affect on the continuation of life: these are hormones, vitamins, antibiotics.

Key words: developmental pharmacology, gerontology, aging processes, geriatric preparations, vitamins, heroprotectors.

Старіння організму, згідно із сучасним уявленням, слід розглядати як процес руйнування живої системи продуктами, що виникають у ході метаболізму, який зумовлює зміни в регуляторних системах, зниження адаптаційних можливостей організму, формування вікової патології і підвищення вірогідності смерті.

У науковому доробку академіка В. В. Фролькіса вагоме місце посідали пошук і дослідження засобів продовження життя. Поштовхом для цього була демографічна ситуація, що склалася в Україні та характеризувалася постарінням населення у результаті росту передчасного та прискореного старіння [16, с. 9-16]. В. В. Фролькіс наголошував, що у ХX ст. більшість біологічних характеристик людини істотно змінилася. У роботі «Интенсификация поисков долголетия» він стверджував, що «Не розгадавши взаємозв'язок між старінням і хворобами, ми не зможемо розробити стійку систему профілактики [7, с. 5]. Найважливіше завдання біологічної і медичної науки знайти й розірвати зв'язок між старінням і хворобою, оскільки «старіння веде до хвороб, хвороби ускладнюють протікання старіння» [9, с. 3].

Учений виділяв два завдання в пошуку засобів продовження тривалості життя в майбутньому: переведення прискореного старіння в уповільнене, тобто використання видових можливостей людини; прорив видового бар'єру тривалості життя.

У 80-х рр. ХХ ст. В. В. Фролькіс обгрунтовує можливість розробки засобів подовження життя. Учений вказує на «три групи чинників, які підтверджують доцільність розробки засобів продовження життя: 1) сама природа створила видову різноманітність тривалого життя...; 2) усередині будь-якого виду, також і людської популяції, є дивні приклади довголіття, тобто можливості особливого шляху вікового розвитку; 3) експериментальна геронтологія вже сьогодні знає підходи до збільшення індивідуальної тривалості життя на 20-30 \%. Тобто успіхи геронтології будуть багато в чому визначатися спільними досягненнями біології та медицини» $[9$, c. 3-6].

В. В. Фролькіс разом із дружиною працювали над вивченням проблеми старіння серцевосудинної системи. Вони одні з перших у світі показала дію препаратів, які впливають на надходження кальцію до клітини та на діяльність серця. Були синтезовані новий клас антиаритмічних засобів, створені антихолінестеразний препарат і реактиватори холінестерази, що застосовуються в клініці, запропоновані інгібітори вазопресину для лікування коронарної недостатності, артеріальної гіпертензії. На сьогодні препарати цього типу широко використовуються в практиці лікування [3, с. 156-163].

Під керівництвом вченого було створено низку геріатричних препаратів: декамевіт, квадевіт, нейрогерін, каглютам, рікавіт, кверцитин, ампевіт, кораргін. Значна частина розробок (включаючи фармацевтичні препарати) була впроваджена у виробництво і медичну практику, хоча перехід до ринку й інші особливості української економіки та менталітету того часу загальмували впровадження низки препаратів в Україні [4, с. 118-120].

Продовжуючи пошук засобів збільшення терміну життя, В. В. Фролькіс наголошував, що це повинні бути засоби, котрі запобігають розвитку захворювань і їх прямий вплив на темп старіння. Ученим вдалося виділити цілий клас спеціальних речовин, які впливають на продовження життя і які були названі геропротекторами (сповільнювачами старіння). В. В. Фролькіс наголошував, що важливо вивчити їх вплив не лише на тривалість життя, а й на функціональний стан організму, на його біологічний вік, щоб знати, яку «ціну» беруть геропротектори за приріст термінів життя. У 80-х рр. XX ст. особлива увага зверталася на такі геропотектори, як сорбенти, антиоксиданти, речовини, що сповільнюють біосинтез білка в 
організмі. Їх вивченням займався колектив експериментального відділу Інституту геронтології на чолі з академіком В. В. Фролькісом [2, с. 28-33].

Аналізуючи метод ентеросорбції, В. В. Фролькіс також указав і на деякі його недоліки. При цьому він зауважив, що «сорбенти зв'язують не тільки токсичні сполуки, але й низку потрібних для організму речовин ... ті, які зв'язують тільки певні речовини» [14, с. 30-39].

Слід зазначити, що Інститут геронтології АМН України за участю академіка В. В. Фролькіса, розробив низку спеціальних харчових продуктів для людей похилого віку, серед яких були кисломолочні продукти «Геролакт», «Геросан», «Лактогеровіт» та ін. На відміну від звичного кефіру, ряжанки, вони містять геропротектори, вітаміни, мінеральні солі. [4, с. 119].

В. В. Фролькіс наголошував, що старіння - процес багатофакторний. Серед факторів прямого впливу на темп старіння велику зацікавленість викликає обмежене харчування - і за кількістю, і головним чином за калорійністю [15, с. 157-186].

В. В. Фролькіс і співробітники Інституту геронтології, вивчаючи зазначену проблему, довели, що «використання дієти навіть у старих тварин дає позитивний ефект і збільшує терміни виживання на 50-100 \%. Важливо, що під впливом подібної дієти відсуваються терміни настання вікової патології та виникнення низки захворювань» [12, с. 14-23]. У результаті дослідження було доведено, що щури живуть довше, коли в їжі зменшено вміст білка. Але вчений застерігав, що зниження калорійності їжі не повинно виснажувати організм людини, і харчовий раціон має складатися з урахуванням індивідуальних особливостей організму [8, с. 26-33].

Цікавим для В. В. Фролькіса в пошуках засобів продовження життя став, як він назвав, «феномен довголіття». Були проаналізовані умови життя, звичаї, харчування, праця не тільки самих довгожителів, а і їхніх родичів різного віку. Традиційно їжа абхазців і азербайджанців низькокалорійна. У раціоні багато рослинних продуктів. Довгожителі, як зазначає В. В. Фролькіс, уживають багато поліненасичених жирних кислот і найбільше біологічно цінної лінолевої кислоти. У їжі довгожителів мало холестерину, зате багато вітамінів і природних антиоксидантів. Останні здатні нейтралізувати вільні радикали [6, с. 207-214].

Таким чином, калорійно обмежена і якісно повноцінна дієта є одним із ефективних методів збільшення тривалості життя, що пов'язано із впливом на весь хід вікового розвитку, на безліч факторів старіння і на найважливіші механізми його протікання.

Академік В. В. Фролькіс доводив, що старіючому організму необхідна достатня кількість вітамінів. В. В. Фролькіс пояснював, що «Самі по собі вітаміни не впливають на тривалість життя. Зате істотно впливають на його якість, бо мають високу фізіологічну активність» $[1, \mathrm{c.} .8]$.

Одним із ефективних засобів продовження життя є активний руховий режим, фізична культура. В. В. Фролькіс стверджував, що ці фактори є могутніми засобами у профілактиці захворювань серцево-судинної системи, а отже, і в подовженні життя [10, с. 15-21].

В. В. Фролькіс зазначав, що одним із перспективних шляхів пошуку засобів подовження життя є використання гормонів. Проводячи досліди, він з'ясував, що зниження впливу деяких гормонів гіпофіза, уведення гормону надниркових залоз, жіночого статевого гормону дещо збільшувало термін життя. А застосування гормонів щитоподібної залози, тестостерону чоловічого статевого гормону, навпаки, скорочують його [13, с. 133-137]. Очевидно, через те, що в організмі існує складний взаємозв'язок у системі нейрогормональної регуляції, уведення одного гормону не може вплинути на подовженість життя. Учений наполягав на необхідності комплексного, системного впливу за допомогою нейрогормональної регуляції.

В. В. Фролькіс приділяв значну увагу проблемі зв'язку між розвитком ракових пухлин і старінням [11, с. 470-484]. Відомо, що частота онкологічних захворювань збільшується з віком. Водночас під час старіння відбуваються зміни, протилежні раковим: у процесі старіння спостерігається сповільнення поділу клітин, при раці - безконтрольний поділ клітин. У таких умовах можуть активізуватися онкогени, онковіруси, які раніше «мовчали». Вчений знайшов вихід: запропонована ним генно-регуляторна терапія, що передбачає використання речовин, які вибірково активізують або пригнічують роботу певних генів, могла б пригнічувати або зовсім знищувати клітини раку.

Таким чином, щоб ліквідувати низку захворювань, не дати клітинам померти необхідно проводити цей процес на рівні генома. Відомо, що апоптоз (смерть клітини) включається під час старіння, інфарктів, дегенеративних пошкодженнях мозку. На відміну від цього процесу, у ракових клітинах апоптоз відсутній. В. В. Фролькіс підтримував і розвивав ідею про активізацію апоптозу в ракових пухлинах, щоб вони самі себе вбивали. 
Ще один із напрямів пошуку засобів подовження життя в дослідницьких роботах академіка В. В. Фролькіса та його співпрацівників пов'язаний із віковими змінами у плазматичній мембрані [17, с. 159-160]. У лабораторії В. В. Фролькіса група співробітників довела існування нового класу внутрішньоклітинних регуляторів, які вони назвали інверторами. Синтезуються вони під контролем генома. Це клас сполук того ж значення, що й місцеві гормони та медіатори... Виділення цих сполук у чистому вигляді (а це тепер робиться) може стати основою для створення нового класу лікарських препаратів із безпосередньою дією [5, с. 5-6].

Отже, наукові пошуки В. В. Фролькіса засобів продовження життя були спрямовані на сповільнення фізіологічних механізмів старіння. Під керівництвом вченого були синтезовані препарати, зокрема новий клас антиаритмічних засобів, створені антіхолінестеразний препарат і реактиватори холінестерази, що застосовуються в клініці. Усі ці препарати зареєстровані як винаходи. За ініціативою академіка В. В. Фролькіса було створено низку геріатричних препаратів - декамевіт, квадевіт, нейрогерін, каглютам, рікавіт, кверцитин, ампевіт, оркомін, кораргін. Значна частина розробок була впроваджена у виробництво і медичну практику. Ученому вдалося виділити цілий клас спеціальних речовин - геропротекторів, які впливають на продовження життя: це гормони, вітаміни, антибіотики. Він наголошував на важливості вивчення їх впливу не лише на тривалість життя, а й на функціональний стан організму, на його біологічний вік, щоб знати, що втрачає організм за збільшення термінів життя. В. В. Фролькіс і співробітники Інституту геронтології АМН України, були «піонерами» в розробці сорбентів.

\section{ДЖЕРЕЛА ТА ЛІТЕРАТУРА}

1. Володимир Фролькіс : Здоров'я - то висота, до якої ведуть сотні стежин / інтерв'ю взяла Т. Мостова // Освіта України. 1999. 31 берез. (№ 13). С. 8.

2. Геропротекторы как гравипротекторы? / В. В. Фролькис, Х. К. Мурадян, А. Н. Тимченко [и др.] // Космічна наука і технології. 1997. № 3/4. С. 28-33.

3. Ингибиторы биосинтеза белка как средство увеличения продолжительности жизни в эксперименте / В. В. Фролькис, Л. Н. Богацкая, А. С. Ступина [и др.] // Геронтология и гериатрия : ежегодник. 1979. Продление жизни : прогнозы, механизмы, контроль. Киев, 1979. С. $156-163$.

4. Кульчицький О. К. Роки до життя і життя до років / Ін-т геронтології АМН України // Ліки України. 2010. № 1 (137). C. 118-120. URL: http://www.health-medix.com/ articles/liki_ukr/2010-01-28/21_GZZG.pdf.

5. Сыкало Н. В. Владимир Фролькис. Жизнь в науке // I Українська конференція молодих вчених, присвячена пам’яті академіка В. В. Фролькіса : матеріали конф., Київ, 31 берез. 1 квіт. 2000 р. / Акад. мед. наук України, Ін-т геронтології АМН України. Київ, 2000. C. $2-8$.

6. Фролькис В. В. Биологические предпосылки увеличения продолжительности жизни // Геронтология и гериатрия : ежегодник 1975. Биологические возможности увеличения продолжительности жизни. Киев, 1976. С. 7-19.

7. Фролькис В. В. Интенсификация поисков долголетия / интерью вел В. Бочкарев // Вечерний Киев. 1986. 10 февр. С. 5.

8. Фролькис В. В. Механизмы долголетия. Долгожители // Геронтология и гериатрия : ежегодник. 1972. Киев, 1973. С. 26-33.

9. Фролькис В. В. Почему мы стареем и болеем? // Зеркало недели. 1995. 21 июля.

10. Фролькис В. В. Старение и механизмы трудовой реабилитации // Геронтология и гериатрия : ежегодник. 1988. Трудовая реабилитация пожилых. Киев, 1988. С. 15-21.

11. Фролькис В. В. Старение и рак : экспозиционно-регуляторные святи // Журнал Академії медичних наук України. 1999. Т. 5, № 3. С. 470-484.

12. Фролькис В. В. Старение : воспоминание о будущем // Лікування та діагностика. 1998. № 1. C. 14-23.

13. Фролькис В. В., Богацкая Л. Н., Вержиковская Н. В. Взаимодействие гипоталамогипофизарной системы и щитовидной железы в различные возрастные периоды // Бюллетень экспериментальной биологии и медицины. 1978. Т. 86, № 8. С. 133-137.

14. Фролькис В. В., Кобзарь А. Л., Тюхтин Г. М. Мембранные механизмы действия тестостерона // Бюллетень экспериментальной биологии и медицины. 1992. Т. 113, № 6. C. 565-567. 
15. Фролькис В. В., Мурадян Х. К. Продление жизни в эксперименте // Физиологические механизмы старения. Киев, 1982. С. 157-186.

16. Фролькіс В. В. Крізь терени старіння до заповітної зірки довголіття // Пульсар. 1999. № 2. C. 9-16.

17. Фролькіс В. В. Мембранні механізми старіння // Розвиток фізіології в УРСР за 1986-1990 роки : зб. матеріалів. Київ, 1990. Т. 2. С. 159-160.

\section{REFERENCES}

1. Mostova, T. (1999). Volodymyr Frolkis : zdorov'ia - to vysota, do yakoi vedut sotni stezhyn [Volodymyr Frolkis: Health is the height to which hundreds of trails lead] Osvita Ukrainy Education of Ukraine, 13, 8 [in Ukrainian].

2. Frol'kis, V. V, Muradyan, Kh. K, Timchenko, A. N. (1997). Geroprotektory kak graviprotektory? [Geroprotectors like gravoprotectors?]. Kosmichna nauka i tekhnolohii - Space science and technology, 3/4, 28-33 [in Ukrainian].

3. Frol'kis, V. V. \& Stupina, A. S. (1979). Ingibitory biosinteza belka kak sredstvo uvelicheniya prodolzhitel'nosti zhizni $\mathrm{v}$ eksperimente [Inhibitors of protein biosynthesis as a means of increasing the life expectancy in the experiment]. Gerontologiya i geriatriya-Gerontology and geriatrics, 156-163 [in Ukrainian].

4. Kulchytskyi, O. K. (2010). Roky do zhyttia i zhyttia do rokiv [Years to life and life to years] Liky Ukrainy - Medications of Ukraine, 1(137), 118-120. Retrieved from http://www.healthmedix.com/articles/liki_ukr/2010-01-28/21_GZZG.pdf [in Ukrainian].

5. Sykalo, N. V. (2000). Vladimir Frolkis. Life in science [Vladimir Frolkis. Life in science]. The Ukrainian conference of young scientists is devoted to the memory of academician V. V. Frolkis: materials of conf. - And the Ukrainian conference of young scientists is devoted to the memory of academician V. V. Frolkis: materials of conf. - Kyiv, 31 March - 1 April. 2000 p. / Acad. honey. Sciences of Ukraine, Institute of Gerontology, Academy of Medical Sciences of Ukraine. (pp. 28). Kyiv [in Ukrainian].

6. Frol'kis, V. V. (1976). Biologicheskie predposylki uvelicheniya prodolzhitel'nosti zhizni [Biological prerequisites for increased life expectancy]. Gerontologiya i geriatriya-Gerontology and geriatrics, 7-19 [in Ukrainian].

7. Frol'kis, V. V. (1986). Intensifikatsiya poiskov dolgoletiya [Intensification of the search for longevity]. Vecherniy Kiev - Nighttime Kiev, 10 fevr., 5 [in Ukrainian].

8. Frol'kis, V. V. (1973). Mekhanizmy dolgoletiya [Longevity mechanisms] Gerontologiya $i$ geriatriya - Gerontology and geriatrics, 26-33 [in Ukrainian].

9. Frol'kis, V. (1995). Pochemu my stareem i boleem? [Why are we getting old and sick?]. Zerkalo nedeli - The mirror of the week, 21 iyulya., 4 [in Ukrainian].

10. Frol'kis, V. V. (1988). Starenie i mekhanizmy trudovoy reabilitatsii [Aging and labor rehabilitation mechanisms] Gerontologiya i geriatriya - Gerontology and geriatrics, 15-21 [in Ukrainian].

11. Frol'kis, V. V. (1999). Starenie i rak : ekspozitsionno-regulyatornye svyazi [Aging and Cancer: Exposure-regulatory Relations]. Zhurnal Akademiï medichnikh nauk Ukraïni-Journal of the Academy of Medical Sciences of Ukraine, (Vols. 5), (pp. 470-484) [in Ukrainian].

12. Frol'kis V. V. (1998). Starenie : vospominanie o budushchem [Aging: a memory of the future]. Likuvannya ta diagnostika - Treatment and diagnosis, 1, 14-23 [in Ukrainian].

13. Frol'kis, V. V. \& Bogatskaya, L. N., \& Verzhikovskaya, N. V. (1978). Vzaimodeystvie gipotalamogipofizarnoy sistemy i shchitovidnoy zhelezy $\mathrm{v}$ razlichnye vozrastnye periody [The interaction of the hypothalamic-pituitary system and the thyroid gland in different age periods]. Byul. eksperim. biologii i meditsiny - Bul experiment biology and medicine, 86, 8, 133-137 [in Ukrainian].

14. Frol'kis, V. V. \& Kobzar, A. L. \& Tyukhtin, G. M. (1992). Membrannye mekhanizmy deystviya testosterona [Membrane mechanisms of testosterone action] Byul. eksperim. biologii i meditsiny Bul experiment biology and medicine, 113, 6, 565-567 [in Ukrainian].

15. Frol'kis, V. V. \& Muradyan, Kh. K. (1982) Prodlenie zhizni v eksperimente [The extension of life in the experiment]. Fiziologicheskie mekhanizmy stareniya-Physiological mechanisms of aging. Kiïv, 157-186 [in Ukrainian].

16. Frolkis, V. V. (1999). Kriz tereny starinnia do zapovitnoi zirky dovholittia [Through the throes of aging to the cherished star of longevity]. Pulsar-Pulsar, 2, 9-16 [in Ukrainian]. 
17. Frolkis, V. V. (1990). Membranni mekhanizmy starinnia [Membranes mehanizmi starinnya]. Rozvytok fiziolohii v URSR za 1986-1990 roky : zb. materialiv-Development of physiology in the Ukrainian SSR for 1986-1990: Sb. materials. (Vols. 2), (pp. 159-160). Kyiv [in Ukrainian].

Одержано 13.04.2019. 